\title{
How coaching aligns the psychological contract between the young millennial professional and the organisation
}

\begin{tabular}{|c|c|}
\hline \multicolumn{2}{|c|}{$\begin{array}{l}\text { Authors: } \\
\text { Chantelle Solomon }{ }^{1} \\
\text { Salome van Coller-Peter }\end{array}$} \\
\hline \multicolumn{2}{|c|}{$\begin{array}{l}\text { Affiliations: } \\
{ }^{1} \text { Management Coaching, } \\
\text { University of Stellenbosch } \\
\text { Business School, } \\
\text { Stellenbosch University, } \\
\text { Cape Town, South Africa }\end{array}$} \\
\hline \multicolumn{2}{|c|}{$\begin{array}{l}\text { Corresponding author: } \\
\text { Chantelle Solomon, } \\
\text { chantelle@shiftsynergy.co.za }\end{array}$} \\
\hline \multicolumn{2}{|c|}{$\begin{array}{l}\text { Dates: } \\
\text { Received: } 03 \text { Dec. } 2018 \\
\text { Accepted: } 28 \text { May } 2019 \\
\text { Published: } 30 \text { Sept. } 2019\end{array}$} \\
\hline \multicolumn{2}{|c|}{$\begin{array}{l}\text { How to cite this article: } \\
\text { Solomon, C., \& Van } \\
\text { Coller-Peter, S. (2019). How } \\
\text { coaching aligns the } \\
\text { psychological contract } \\
\text { between the young millennial } \\
\text { professional and the } \\
\text { organisation. SA Journal of } \\
\text { Human Resource } \\
\text { Management/SA Tydskrif vir } \\
\text { Menslikehulpbronbestuur, } \\
\text { 17(0), a1146. https://doi.org/ } \\
\text { 10.4102/sajhrm.v17i0.1146 }\end{array}$} \\
\hline \multicolumn{2}{|c|}{$\begin{array}{l}\text { Copyright: } \\
\text { (c) 2019. The Authors. } \\
\text { Licensee: AOSIS. This } \\
\text { is licensed under the } \\
\text { Creative Commons } \\
\text { Attribution License. }\end{array}$} \\
\hline \multicolumn{2}{|l|}{ Read online: } \\
\hline 回的回 & $\begin{array}{l}\text { Scan this QR } \\
\text { code with your } \\
\text { smart phone or } \\
\text { mobile device } \\
\text { to read online. }\end{array}$ \\
\hline
\end{tabular}

Orientation: Coaching has the potential to align the expectations between young millennial professionals and their organisations as coaching in a business context should result in mutually beneficial outcomes valued by both the coachee and the organisation.

Research purpose: The research reported in this article explored how coaching contributes to the alignment of the psychological contract between an organisation and the young millennial professional.

Motivation for the study: The work-related preferences and expectations of millennials can result in misalignment in the psychological contract between organisations and young millennial professionals, negatively affecting their level of engagement; performance and tenure. There is a paucity of research into building psychological contract mutuality and the coaching of millennials.

Research approach/design and method: A phenomenological approach within a qualitative research design was followed. This included semi-structured interviews with seven young millennial professionals who had been coached and email interviews with five coaches who had coached young millennial professionals.

Main findings: Coaching can enhance the psychological contract between young millennial professionals and their organisations, particularly with regard to career development. Alignment in expectations regarding career development may result in improved performance; enhanced affective commitment and lower turnover.

Practical/managerial implications: Coaching is a viable strategy for organisations to engage and retain their young millennial professionals by cultivating psychological contract alignment in the employer-employee relationship.

Contribution/value-add: This research supplements the limited body of knowledge on building psychological contract mutuality and coaching efficacy for young millennials.

Keywords: coaching; millennials; millennial professionals; psychological contract; career development; generational differences.

\section{Introduction}

There are three generations working alongside each other in the workplace today. Engaging, managing and retaining millennials is topical (Sinek, 2016, cited in Gosse, 2017 ) with many managers wondering whether it is just their own perception or whether what inspires, motivates and challenges this young generation of workers really is different from that of previous generations (Twenge \& Campbell, 2012).

According to a report by PricewaterhouseCoopers one of the biggest talent challenges for organisations is attracting and retaining these younger workers (PWC, 2011). A survey conducted by Deloitte (2016) revealed that globally, two-thirds of millennials expect to leave their current organisation in 5 years. Millennials in emerging markets are the least loyal to their current organisation. In South Africa, $76 \%$ of millennials expect to leave their current organisation in 5 years (Deloitte, 2016).

The work-related preferences and expectations of millennials can result in misalignment in the psychological contract (PC) between organisations and young millennial professionals (YMPs), which can negatively affect their level of engagement, performance and tenure. Young millennial 
professionals just entering the workplace have expectations of mutual obligations between themselves and their organisations. As YMPs have grown up with significantly different experiences, technology and culture than previous generations, they are perceived to have different work-related preferences that shape their expectations (Coetzee, Ferreira, \&Shunmugum, 2017; Lub, Blomme, \& Bal, 2011). Similarly, organisations have expectations of the mutual commitments between themselves and these young professionals. Psychological contracts (PCs) are 'an individual's beliefs concerning reciprocal obligations' in the employment relationship (Rousseau, 1990, p. 9). PC fulfilment and its suggested business benefits are more likely to materialise if the parties agree about their obligations towards each other (Rousseau, 2001). A salient characteristic of PCs is the individual's perception that the understanding regarding reciprocal obligations is mutual. With PCs operating on the perception of agreement, the key challenge for PCs is how to create and maintain mutuality between the parties (Rousseau, 2001).

Coaching, in a business context, should result in mutually beneficial outcomes of value to both the coachee and the organisation (Kahn, 2014) begging the question as to how coaching might contribute to aligning the PC between these young workers and their organisations.

\section{Research purpose}

This article reports on a study exploring how coaching contributes towards aligning the PC between YMPs and their organisations. In the study, YMPs were defined as individuals under the age of 30 who have just embarked on their careers or who are building their career within an organisation in a corporate environment. Our focus on individuals under the age of 30 addressed the topical nature of managing millennials and their expectations in the workplace. Although extensive research has been carried out on the consequences of PC violations between parties (Rousseau, 2001), a smaller body of research is focused on how PCs between individuals and organisations are formed and maintained and how they change over time. Similarly, there is a paucity of scholarly research specifically addressing coaching millennials: only one peerreviewed article (Franklin, 2015) was identified.

Insights from this article provide management-, human resource- and coaching practitioners with a clearer idea of which benefits from coaching may contribute towards cultivating mutuality in PCs between YMP's and their organisations. It also sheds light on the content dimensions of millennials PCs, which may be met through coaching. Lastly, it highlights the potential business benefits that can flow to the organisation, influencing the engagement and retention of these workers.

\section{Literature review}

Firstly, the literature provides insights into the generation known as millennials. Secondly, aspects of PC theory that influence alignment are emphasised, namely the concept of mutuality, and the formation, maintenance and change of PCs as well as their content. Finally, the potential of coaching as a contributing factor towards aligning the PC between YMPs and their organisation is presented.

Although the origins of the PC date back to the 1960s, most scholarly research on PCs cite Denise Rousseau's work as the original source. Rousseau's voice is predominant regarding the underlying concepts of PC theory presented in this article.

\section{Who are the millennials?}

Millennials are the largest generation in history (PWC, 2011). Millennials have been entering the workplace approximately from the year 2000, and will comprise $50 \%$ of the worldwide workforce by 2020 (PWC, 2011). They will soon outnumber their Generation X predecessors (born 1965-1980) in the workplace, and are no longer considered the leaders of tomorrow, but the leaders of today (Deloitte, 2016). Millenials' formative experiences, their characteristics and values as a generation are highlighted first.

Born between the early 1980s and late 1990s (Twenge, 2010), millennials grew up during times of economic prosperity, the rise of the Internet, the fall of the Berlin Wall and the war on terror following the attacks on the Twin Towers on 11 September 2001 (Dries, Pepermans, \& De Kerpel 2008; Twenge \& Campbell, 2012). Media and popular literature portray millennials as idealistic, optimistic, confident, not cowed by authority (Alsop, 2008), innovative and adaptive and not fearing change (Wasserman, 2017). It is postulated that although they come across as confident and articulate, millennials have lower self-esteem than earlier generations, and require constant reassurance (Gosse, 2017). Parenting strategies such as helicopter parenting (Wasserman, 2017), where parents are overprotective of their children, have led to young adults with higher levels of anxiety, without mechanisms to cope with stress or failure (Gosse, 2017). Constant access to the Internet and social media has influenced millennial-relationships with their peers and other generations (Gosse, 2017). They are portrayed as shallow, unable to form meaningful relationships and loyal to others only for as long as it suits them (Twenge \& Campbell, 2012).

Within the workplace, millennials are recognised for using their technological shrewdness to enhance their productivity, efficiency and collaboration with others (Burrows, 2013). They desire to shape their workplace (Burrows, 2013) and can be influential brand ambassadors if they buy into an organisation's purpose (Wasserman, 2017). Millennials are also apparently 'tough to manage' (Gosse, 2017) often popularly described as entitled, lazy and inappropriately demanding (Alsop, 2008). This techno-generation prefers to communicate electronically rather than face to face (Myers \& Sadaghiani, 2010). In addition, they are eager to move onto new and different challenges at work 
(Ng, Schweitzer, \& Lyons, 2010). Technology has exacerbated their sense of impatience, feeding the instant gratification tendencies of these young people who are used to getting what they want as soon as they want it (Gosse, 2017).

The work-related expectations of millennials are embodied in their PCs. Certain key constructs of PC theory relevant to this article are addressed next, considering their influence on millennials PCs where applicable.

\section{The psychological contract}

The PC is specifically concerned with the expectations of inputs and outcomes exchanged in the employer-employee relationship. Rousseau defined the PC as 'individual beliefs regarding terms of an exchange agreement between individuals and their organisation' (Rousseau 1995, p. 9). According to Rousseau, beliefs become contractual where an employee believes they are obliged to perform or behave in a particular way (for example, high performance, sacrifices, and managing their own careers) and that the employer has particular obligations towards them (high pay, promotion, and training and development) (Rousseau, 1990). Research over the last 30 years supports that employees are motivated to reciprocate what they believe to be commitments fulfilled by their organisation and promised inducements.

\section{Psychological contract mutuality}

Psychological contracts are more likely to be fulfilled if there is agreement between employee and employer on their obligations towards each other. Shared understanding aligns behaviour, reduces insecurity and encourages reliance on anticipated future exchanges (Rousseau, 2004). This leads to higher productivity and more supportive and constructive interactions between individuals and organisations (Dabos \& Rousseau, 2004; Rousseau, 1995, 2001). The absence of mutuality in PCs can result in assumptions that promises are unfulfilled, PC breach and violation (Ye, Cardon, \& Rivera, 2012), which in turn influence employee attitudes and performance outcomes (Coyle-Shapiro \& Kessler, 2000; Ye et al., 2012). Employment relationships can be easier to sustain with mutuality in place (Persson \& Wasieleski, 2015).

Research on factors contributing to a shared understanding in PCs is limited (Dabos \& Rousseau, 2004). Mutuality is fostered where information relevant to the context of the exchange is shared openly and frequently between the parties, leading to collective frames of reference (Dabos \& Rousseau, 2004). Sharing of information between the parties to the PC is crucial to its sustainability. Psychological contracts require sense-making in the working environment as they are premised on perceptions, expectations and emotions (Persson \& Wasieleski, 2015). A further challenge is how to motivate employees to share their knowledge to produce mutuality (Rousseau, 2001) as motivation is influenced by both individual and contextual factors (Persson \& Wasieleski, 2015).
Formation, maintenance and change of psychological contracts

Psychological contracts are a form of schema (Rousseau, 2001). A schema is constructed from experience, subsequently influencing how later information is processed and organised (Stein, 1992, cited in Rousseau, 2001). Psychological contract schemas are shaped by pre-employment experiences, recruitment interactions, early socialisation in an organisation (Rousseau, 2001), interactions with managers, co-workers and human resource processes (Dabos \& Rousseau, 2004). Broader societal factors and economic and organisational changes also influence PC construction. As schemas, PCs are initially incomplete and require fleshing out over time. Psychological contracts often become more complex and more implicit as the employment relationship develops (Rousseau, 2004). As PCs achieve a level of completeness, these schemas become relatively stable and resistant to change. Experiences are subsequently viewed through the lens of the existing schema (Rousseau, 2001).

Individuals from different generational cohorts experience different circumstances and events during their formative life-stage and create different schemas about their world of work, resulting in the development of 'generationally specific perceived employer obligations' (Lub, Bal, Blomme, \& Schalk, 2016, p. 655). These schemas influence the content of PCs and an individual's sense-making around reciprocity and mutuality that should be demonstrated by parties to the employment arrangement (Dabos \& Rousseau, 2004; Lub et al., 2016).

Various formative experiences may have shaped millennials' schemas about the world of work. Millennials grew up in a prosperous yet uncertain global economic climate, and lived through the 2002 dot-com bubble burst and 2008 global financial crisis (Gosse, 2017). They watched as several major corporations (Enron, Arthur Andersen, Barings Bank) were brought to their knees through unethical leadership and dubious business practices (Twenge \& Campbell, 2012), and saw their own parents' commitment to their careers being 'rewarded' by downsizing and retrenchments (Lyons \& Kuron, 2014). The advancement of the Internet has influenced their values, and they are comfortable in fast-paced high-tech environments (Lub et al., 2016).

Psychological contract construction is further shaped by socialisation in the organisation and organisational changes rooted in societal trends. Hess and Jepsen (2009) assert that restructuring and downsizing, technological changes and other labour market changes have resulted in a PC shift from an organisational career to a protean career. In a protean career, employees take responsibility for their own career management, aiming to build skills to enhance their employability. The organisation is expected to afford opportunities to grow and develop at work (Hess \& Jepsen, 2009). 


\section{Content of psychological contracts}

Since the parties to a PC have their personal perception of the obligations implicit in the contract, it is difficult to define and evaluate the precise content of the PC (Freese \& Schalk, 2005; Persson \& Wasieleski, 2015). Rousseau adopted the distinction of transactional and relational contracts, and defined features of these contracts in the workplace using dimensions such as focus, time frame, stability, scope and tangibility. Other researchers have identified a variety of PC content dimensions such as job content, reward and job security (Herriot, Manning, \& Kidd, 1997; Kultalahti \& Viitala, 2015; Lub et al., 2016). The content dimension perspective was adopted in this study in line with more recent studies on millennials and their PCs (De Hauw \& De Vos, 2010; Kultalahti \& Viitala, 2015; Lub et al., 2016).

The literature revealed that millennials value meaningful work (Dries et al., 2008), challenging, interesting and varied job content (De Hauw \& De Vos, 2010; Kultalahti \& Viitala, 2015) and a supportive and nurturing work environment (Kultalahti \& Viitala, 2015). They appreciate a social atmosphere and cooperation between colleagues at work (Cennamo \& Gardner, 2011; Wong, Gardiner, Lang, \& Coulon, 2008). Millennials expect supervisors to set high demands and provide clear direction, balanced with a degree of flexibility to do things their way, and to learn by trial and error (Kultalahti \& Viitala, 2015). Evidence suggests that millennials have a higher need for recognition and appreciation (Wong et al., 2008) and value regular feedback more often (Kultalahti \& Viitala, 2015; Wasserman, 2017). Salary is as important for millennials as for previous generations (Dries et al., 2008; Lub et al., 2011), though they prize instant bonuses and various perks when recognised for their contributions (Kultalahti \& Viitala, 2015).

A decline in work-centrality alongside an increase in leisure values (Twenge, Campbell, Hoffman, \& Lance, 2010; WrayLake, Syvertsen, Briddell, Osgood, \& Flanagan, 2011) supports the perception that millennials 'work to live' rather than 'live to work' (Lyons \& Kuron, 2014). They appreciate respect for their personal circumstances and expect reciprocal flexibility regarding working hours (Cennamo \& Gardner, 2011; De Hauw \& De Vos, 2010). Young millennials appear willing to sacrifice work-life balance in the interim to find a satisfying career.

Millennials value self-actualisation through growth and development (Kultalahti \& Viitala, 2015; Lub et al., 2011). Millennials are expected to manage their own careers, for example through demonstrating visibility behaviours and generating their own career opportunities; in return they expect their employer to provide training and development opportunities and assist in realising their career opportunities (Hess \& Jepsen, 2009).

As these beliefs are from the perspective of the millennial employee only, aligning or creating mutuality in the PC with their organisation requires articulating and negotiating such beliefs with appropriate agents of the organisation. In the following section, the potential of coaching to cultivate mutuality in PCs is explored with reference to research into coaching efficacy.

\section{Coaching and cultivating mutuality in psychological contracts}

Coaching in the workplace is a goal-focused and reflective learning partnership between a coach and a coachee (ICF, 2017; Jones, Woods, \& Guillaume, 2016), focused on facilitating sustainable changes in thinking, feeling and behaviour (Douglas \& McCauley, 1999) that result in the attainment of mutually beneficial outcomes valued by the coachee and the organisation (Kahn, 2014). In this study, we focused on external coaches involved in one-on-one discussions with coachees owing to our interest in coaching's impact in its purest sense rather than where a manager uses a coaching leadership style.

A key aspect to cultivating mutuality in PCs is frequent and open sharing of information between the parties. Prior to and after this event, there is a need for individual sense-making and delving into the beliefs around reciprocal obligations implicit in the PC, as well as for the motivation to share information. In this context, it is our contention that coaching may provide an appropriate vehicle for such sense-making and exploration regarding beliefs and motivations to take place. Because no clear empirical links have been made between PCs and coaching, we explored coaching's potential to produce alignment in PCs by examining the empirical evidence supporting coaching effectiveness. The question asked in reviewing the literature around coaching efficacy was, 'what recognised effects of coaching can potentially contribute towards cultivating mutuality in PCs between an employee and their organisation?'

The research on coaching effectiveness reveals a number of benefits of coaching that may contribute towards cultivating mutuality in PCs. Kombarakaran, Yang, Baker and Fernandes (2008) found that coaching resulted in increased communication and an improved relationship with direct supervisors citing 'better understanding of how to work with my manager' (Kombarakaran et al., 2008:85). Improved relationships in the workplace was a clear theme in reported coaching benefits in the Sherpa 2017 Executive Coaching Survey (Sherpa Coaching, 2017). Better relationships and more communication may positively influence an individual's motivation to share information related to their PC beliefs with their managers, increase the frequency and openness of sharing, and provide a useful approach to situations where perceived differences in PC obligations arise (Rousseau, 2001).

Le Sueur and Tapela (2018) found that coaching raised awareness about coachees' perceptions of themselves. Kombarakaran et al. (2008:83) noted that coaching resulted in a 'better understanding of personal strengths'. This personal insight and growing confidence about their own abilities gained through increased self-awareness (Grant, Curtayne, \& Burton, 2009) may potentially influence PC mutuality by 
helping individuals to make sense of their beliefs in the reciprocal obligations between themselves and the company, and to identify what is important to them and what their motivations are. Improved clarity of expectations and the enhanced ability to define performance goals more clearly (Kombarakaran et al., 2008) may allow individuals to be more confident to articulate their perspectives in sharing such information with their managers or working to resolve perceived differences in their PCs.

As millennials place high value on work-life balance (Kultalahti \& Viitala, 2015), coaching may help them to address their needs for balance with agents of the organisation more effectively (Simpson, 2010), influencing mutuality of the $\mathrm{PC}$ in this specific area.

\section{Research methodology Research approach}

This study utilised constructivist phenomenological principles within the exploratory qualitative research genre. This approach was considered appropriate because we wanted to understand and describe the core commonality of how the lived experience of being coached contributed to aligning the PC between YMPs and their organisations (Creswell, 2007) on the basis of the multiple realities and collective reconstructions of the research participants (Denzin \& Lincoln, 2005). Babbie and Mouton (2015) support this approach, saying that exploratory qualitative research emphasises describing and understanding a phenomenon from the social actors' perspectives, rather than explaining it.

\section{Sampling strategy and population}

Purposive sampling, a method characteristic of qualitative phenomenological research design (Babbie \& Mouton, 2015), was used to identify participants. The most likely source of data was YMP's who had been coached in their organisations (coachee participants) as well as coaches who had coached this population group (coach participants). Collecting data from coach participants as well as coachee participants was a form of triangulation used to enhance the credibility of the study (Babbie \& Mouton, 2015). Potential candidates were approached through two avenues, namely requesting permission from organisations themselves and via personal networking. Key inclusion criteria were that coachee participants be younger than 30 years old to fit within the definition of 'YMP' for this study, and have been coached, not mentored. Similarly, coach participants must have coached, not mentored, YMPs under the age of 30 in organisations. Seven coachee participants were sourced across four corporate organisations in South Africa. Five coach participants were sourced, of which four were external coaches in private practice, and one was an internal coach in a corporate organisation. There were an equal number of male and female participants across the entire sample. The contexts in which the coaching took place were individual coaching supporting a development or internship programme, or stand-alone individual coaching where the desired outcomes from the coaching differed between individuals. All coachee participants had experienced at least six coaching sessions sponsored by the organisation. Coaches described their experiences referring to the YMPs they had coached to date.

\section{Data collection}

Semi-structured interviews were conducted with coachees and email conversations with coach participants. The coachee one-on-one interviews were conducted from 25 April 2017 to 14 June 2017. Semi-structured interviews allowed flexibility via probing questions, producing richer and more detailed responses (Babbie \& Mouton, 2015). The interview guide explored coachee's perceptions of the outcomes they realised from the coaching process and investigated the contribution of these outcomes to the alignment of the PC between themselves and their organisations. The interview guide was constructed based on the indicators of PCs identified in the literature (Rabionet, 2011).

Email interviews were used to collect data from coach participants. Selecting the email interview method of data collection allowed for obtaining rich descriptions (Gibson, 2010) and, at the same time, working more time- and costefficiently. These questions explored coaches' experience of coaching YMPs, their perception of the professional and personal outcomes for these young workers from the coaching and more specifically their sense of how the coaching contributed to aligning the PC between these young professionals and the organisation. Email responses were carefully reviewed and follow-up questions were asked for clarification or elaboration where required (Gibson, 2010). From 25 April to 4 July 2017, between two and four emails were exchanged with each coach participant.

\section{Data analysis}

Within the inductive analysis framework, the researcher chose to use the thematic analysis approach of Braun and Clarke (2006) as it supports the exploration of individual perspectives, enabling interpretation of the broader meaning of what participants have said (Crowe, Inder, \& Porter, 2015). The researcher immersed herself in the data, identified and coded the data that met the research objectives, clustered the codes into categories and then analysed the data to uncover emergent themes and relationships. Having reviewed the themes, the researcher considered the relationship between them and identified the quotes that provided rich data to support her findings. Thereafter, the researcher wrote up the narrative on the basis of the integration of the analysis described above.

\section{Ethical considerations}

Ethical boundaries of both the coaching profession and the researcher's academic institution were applied from conception to collection and analysis of the data. Participants acknowledged their awareness of their rights 
as participants of the study by signing informed consent documents. In two instances, organisational permission to gain access to coachee participants was obtained. Participation of candidates from these organisations was voluntary even if the organisation agreed to grant access to the participants. Each participant was assigned an alpha character to assure anonymity throughout the study; furthermore, findings and insights were represented on an aggregated basis

\section{Findings and discussion}

Findings in respect of key outcomes from coaching experienced by coachee participants (randomly coded A to G) and how they perceived that these outcomes contributed towards aligning their PC with their organisation are presented in this section. Corroborative observations from coach participants (randomly coded V to Z) are included where relevant.

Coachees revealed that enhanced awareness, improved confidence and increased ability and motivation to handle tough conversations are three key outcomes of coaching that contributed towards aligning their PC with their organisation.

\section{Enhanced awareness}

Enhanced awareness was experienced in three distinct areas, namely deeper self-awareness, a growing awareness of selfresponsibility and a more realistic sense of the value they bring to the organisation.

Coachee participants in this study gained deeper self-awareness into these aspects:

- their personality, their thinking and assumptions (B, C \& F),

- exploration of their values (B \& F), recognition of the strengths and areas of development (C \& F),

- appreciation of their behaviours and how these behaviours influence their interactions in the organisation (C\&F) and understanding of what they want from life and work on the basis of knowing who they are (C, E \& F).

Both Le Sueur and Tapela (2018) and Kombarakaran et al. (2008) cited enhanced self-awareness as a benefit of coaching. The clearer sense of their identity and self-appreciation raised their awareness about what they wanted regarding their development and career progression. Coachee participants appeared to become more intentional about the next step in their careers, an outcome supported by Simpson (2010) as described in the quote below:

' $[I] \mathrm{t}^{\prime}$ s raised awareness about who I am and what I want, what I enjoy, where my strengths lie, where my weaknesses are ... I want to use my strengths and make sure that they remain strengths. I also want to work on my weaknesses and turn them into strengths if possible. That made me very deliberate about where I want to go into the organisation.' (Participant C, male, coachee)
Coachee participants recognised through coaching that it is their responsibility to pursue their goals ( $\mathrm{D} \& \mathrm{~F}$ ). Coach $\mathrm{X}$ observed that 'the realisation of personal accountability' is an outcome of coaching for these young workers. Jones et al. (2016, p. 252) claim that coaching helps to instil selfresponsibility as coaching is focused on active learning and gives the coachee control over their learning and development. Acknowledging self-responsibility through coaching may help YMPs grasp that they must take the first step to raise awareness of their PC beliefs with their organisation, especially where they perceive differences in the understanding of the obligations.

Both coachee $(\mathrm{C} \& \mathrm{E})$ and coach participants $(\mathrm{X} \& \mathrm{~V})$ perceived that coaching enhanced the young workers' awareness of their value in the organisation, for example:

'It really helped me professionally understand myself and know what I offer as an individual.' (Participant E, female, coachee)

Le Sueur and Tapela (2018) noted that coaching raises awareness about individuals' contribution to their work. With millennials often popularly characterised as egocentric and entitled (Alsop, 2008), perspective taking is a further benefit of self-awareness (Silvia \& O'Brien, 2004) for these young workers as highlighted by this comment:

'The world does not owe you anything ... something I've realised more through coaching. I should not come to [Company XYZ] being young and black [and a Chartered Accountant] and expect myself to be promoted on the basis that they needed me ... I need to add value, show my worth to the organisation.' (Participant F, male, coachee)

Our sense is that a more accurate view of the value that they bring moderates YMPs' beliefs concerning the reciprocal obligations between themselves and the organisation, potentially creating a frame for more credible PC discussions between employee and employer.

\section{Improved confidence}

Coachees experienced increased confidence in the areas of speaking up and taking action regarding their development. Coachees highlighted that their growing confidence flowed from enhanced self-awareness (C, E), a notion supported by Henderson (2016).

Coachees felt more confident to ask for help (B \& G) and to challenge situations that did not feel right for them (C \& G). Coachees described having more confidence to raise awareness of themselves, their abilities and their beliefs regarding elements of their PCs with their organisation (C \& D). Coach $X$ affirmed this finding:

'Its [coaching] also enabled them to find a voice and be able to have honest and specific conversations with the organisation re their expectations as well.' (Participant X, female, coach)

Coachee participants perceived that they are responsible for taking action regarding their career development in their 
organisations (C, F \& G) confirming the PC shift from an organisational to a protean career, where employees take on their own career management alluded to by Hess and Jepsen (2009) and Low, Bordia and Bordia (2016). Furthermore, they felt strongly that their increased confidence from coaching was a catalyst to act on their development as demonstrated in one coachee's statement:

'It's not just me coming in here to do a job. It is also about the job developing me and if it doesn't I'm more confident now to do something about it.' (Participant $C$, male, coachee)

The changed behaviours of speaking up about reciprocal obligations and taking action regarding personal development needs are significant in the context of this research. Speaking up implies that YMPs may feel more confident to communicate their PC beliefs with their organisation, thus enhancing the potential for PC alignment and fulfilment. Further, because millennials acknowledge that the organisation expects them to manage their own career (Hess \& Jepsen, 2009), having confidence to take action regarding their own development and career progression might contribute towards fulfilment of the organisation's expectations of the employee.

\section{Individuals' efficacy and motivation to handle tough conversations}

Conversations regarding beliefs in PC obligations are potentially difficult as they may expose opposing opinions, and results or relationships may be at stake. Coachee participants perceived that coaching helped them in their approach to these conversations. As one coachee expressed:

'... the method, maybe how and when as well ... finding a way to raise it as an issue, a mature way ... not just complaining ... I found the right situation to raise my issues, the right places. I was able to communicate better with less of making it seem as if it's a personal attack against someone.' (Participant D, female, coachee)

Coaches confirmed that coaching has helped their clients to have hard conversations that address situations where they had identified differences in the understanding of the obligations between themselves and the organisation (X \& Y). Some coachee participants observed that they had open and reasonably frequent communication with their managers regarding their PC beliefs (D \& F). Kombarakaran et al. (2008) cited dialogue that is more effective and open communication between individuals and their managers as an outcome of coaching. It appears that (having improved their skills to address tough conversations) they were motivated to have potentially difficult conversations more frequently to ensure mutuality. This is consistent with Grenny, Patterson, Maxfield, McMillan and Switzler's argument that increased motivation often follows enhanced capability (2013). The business benefit is that productive conversations are held more regularly, thus enhancing the potential for PC alignment and fulfilment.

Although the majority of research participants in the studies on coaching effectiveness are executives at senior- and middle-management levels, there is commonality in the reported benefits from literature and the key outcomes described by the coachees in this study - namely that of enhanced awareness and increased communication with managers described by the coachees in this study. This suggests that YMPs may experience similar effects from being coached as more senior individuals in the organisation regardless of their generation.

\section{Psychological contract content dimensions where alignment was enhanced through coaching}

Coachee participants highlighted three areas where coaching played a role in enhancing the mutuality in the PC between themselves and their organisations, namely alignment of values (B), fit within the organisation $(\mathrm{C} \& \mathrm{~F})$ and career development (all coachee participants).

Consistent with Lub et al.'s (2016) findings, coachees believed that they are expected to take responsibility for their own career development (A, C, F \& G). In addition, they believed that where they do engage in individual career development activities, such as speaking up about their development needs, they expect help and support from the organisation to achieve their objectives. One coachee states this clearly:

'... The expectation of the company is that if you're interested in
developing your career you'll make the first move. You are
provided with mentors, coaches and things like that, but you
also need to, kind of, ask as well. On the other hand, my
expectation is that if I do ask, I expect my manager to help me ...'
(Participant C, male, coachee)

Coachees expressed that perceived fulfilment of the PC through the career management support they receive from the organisation influenced them in two pertinent ways: It encouraged them to step up to what they believe to be their obligations to the organisation in terms of their current or future roles $(B, F \& G)$. Coachee $F$ described this obligation as a 'higher level of engagement with his body of work'. Coachee $G$ spoke about learning the most he can from the coaching to be ready to step into his next role. Coyle-Shapiro and Kessler (2002) made similar findings postulating, 'perceived employer fulfilment of their obligations creates an obligation on employees to reciprocate and this takes the form of a cognitive upward adjustment in employees' obligations to their employer' (Coyle-Shapiro \& Kessler, 2002 , p. 83). Secondly, the respondents appeared reluctant to leave their organisations for other opportunities, including financial benefits (B, C \& F) as explicitly set out by one coachee:

'I sometimes get offers on LinkedIn or offers from other companies, even though the money is more ... it's very hard for me to take any other offers seriously, especially when I consider things that the company has taken me through and the money that they've spent on developing me as a person.' (Participant $C$, male, coachee)

This attachment implies a strong affective commitment towards the organisation. Affective commitment refers to 
an employee's identification with an organisation's goals and values; they feel a strong emotional connection to the organisation and the work they do (Conway, Guest, Sturges, \& Liefooghe, 2005). Higher affective commitment suggests that millennials' need for meaningful work (Dries et al., 2008) and a sense of purpose (Deloitte, 2016) are met. Conway et al. (2005) confirmed that this suggested a link between PC fulfilment relating to career development and affective commitment. Zhao, Wayne, Glibkowski and Bravo (2007) found that affective commitment is positively associated with actual performance and lower turnover.

Coach participants observed that coachees might perceive receiving coaching as a key aspect of the organisation fulfilling their PC beliefs regarding career development. This observation is illustrated in this comment:

'I think they feel that the company appreciates them and acknowledges their potential (typically only the top performers who have been earmarked for fast track promotion are exposed to coaching). It plants a seed for future personal development ...' (Participant Z, male, coach)

Aspects that stood out from the coaches' input are that the millennials who received coaching felt that the organisation cared for them (Y); they felt acknowledged and appreciated $(Y, Z$ \& V). Coachee participants indicated that being coached fulfilled an aspect of their PC; they felt that the company invested in them because they had recognised their potential (C, E \& F). According to Festing and Schafer (2014), coaching reflects the notion of an investment in a long-term and stable relationship with an employee, and relays important signals to talented individuals in organisations. Our sense of these findings is that coaching contributes to the fulfilment of YMPs' PCs by meeting their needs for growth and development (Lub et al., 2011) in a supportive, nurturing work environment (Kultalahti \& Viitala, 2015), as well as their need for recognition and appreciation (Kultalahti \& Viitala, 2015; Wong et al., 2008). A more fulfilled PC in turn may lead to suggested outcomes such as improved performance, job satisfaction and organisational commitment (Festing \& Schafer, 2014).

\section{Practical implications}

The implications that can be practically applied by managers, human resource practitioners and coaches are:

- Positioning coaching as an investment in the coachee is the first step towards PC fulfilment in the content dimensions of career development, reward (which includes recognition) and tenure.

- Using coaching as a viable strategy for organisations to cultivate PC alignment with their YMPs, either implicitly or explicitly and particularly in the psychological content dimension of career development.

- Conversations concerning reciprocal obligations are potentially difficult as there may be opposing opinions and high stakes involved. It is suggested that coaching outcomes include equipping coachees with the skills and motivation to have tough and productive conversations with their managers and other agents of the organisation.

Other practical implications all three professional groups can consider as a result of this study are:

- Coaching may promote more robust and credible discussions between managers and YMPs regarding their reciprocal obligations in the employer-employee relationship.

- YMP's who have been coached may realise the benefits of coaching such as enhanced self-awareness, improved confidence and ability to have tough conversations earlier on in their careers. This could boost their leadership development as well as their organisational effectiveness.

\section{Limitations of the study and recommendations for future research}

To explore the phenomenon in question, seven YMPs who had experienced coaching were interviewed. The addition of five coaches' perspectives enhanced the richness and credibility of the data collected. Future research, where only coachee perspectives are collected, might consider extending the number of coachee participants interviewed to at least 10 to 12 respondents to ensure that data saturation is achieved.

Some suggestions for further research emanating from this study are:

- The findings of this study are from the perspective of the YMPs and the coaches only. Future researchers may consider obtaining evidence from managers of the coachee participants. This might provide a complete and potentially more balanced perspective of the phenomenon.

- Because the coaching of millennials is an underresearched topic, further exploration of how millennials experience coaching, and some of the other outcomes millennials realise through coaching would be a useful contribution to the literature.

- There is limited research into the content of PCs from the perspective of both the employee and the employer, and a dearth of research into PC mutuality. With $50 \%$ of millennials already in formal leadership positions (Deloitte, 2016), there is an opportunity to explore the content of the PC from the respective views of the millennials employees and their millennials managers. It would be interesting to investigate whether PC mutuality is in any way influenced by the fact that both employee and employer are of the same generation.

\section{Conclusion}

This study sheds light on the role of coaching in aligning expectations between YMPs and their organisations. Where YMP coachees achieve certain internal outcomes from a coaching process, they may be motivated to take up behaviours that contribute towards cultivating mutuality in the PC between themselves and their organisation. Leedham's (2005) Coaching Benefits Pyramid model 
resonated with our findings. He suggested that realising inner personal benefits from coaching, such as clarity and improved confidence, lays the foundation for achieving outer personal benefits such as change in behaviours, or enhanced knowledge, skills and understanding, ultimately leading to business benefits. Figure 1 is a pyramid adapted by adding the specific findings of the present study as related to Leedham's model.

The Coaching and PC Alignment pyramid suggests that coaching can viably contribute to the alignment of the PC between the YMP and their organisation. This alignment may be initiated via the realisation of inner personal benefits for the coachee from the coaching as described by the coachee participants in this study:

- Coachees gained an enhanced awareness of who they are (strengths, personality, and values) and what they want from life and work. They were able to articulate their development needs and direction more clearly. They became more aware of their responsibility to raise their PC beliefs with the organisation. Their more accurate view of the value they bring to the organisation appeared to moderate their PC beliefs, potentially creating a frame for more credible discussions regarding reciprocal obligations. Coachees noticed that improved confidence flowed from their enhanced personal insight.

The perceived outer personal benefits experienced by the coachee participants and affirmed by the coach participants were:

- Coachees observed that their improved confidence enabled them to speak up more credibly about their strengths and contributions, and to hold conversations that contributed towards clarifying the organisation's expectations of them, and what they expected in return. Further, it appears that coaching assisted them in their ability to handle tough conversations, imparting both the skills and motivation to have candid and respectful conversations with their managers regarding their PC beliefs.

- Coachees noticed that they were more confident to take action concerning their own development. As organisations now expect employees to manage their own careers, this may contribute towards fulfilment of the organisation's expectations on the part of the employee.

With the improved behaviours and enhanced skills in place, it appears from this study that the potential for both the coachee and the organisation to realise PC alignment and fulfilment particularly in the content dimension of career development is enhanced. Mutuality in the reciprocal obligations regarding career development speaks directly to the millennials' need for self-actualisation through growth and development and contributes to providing the supportive and nurturing work environment in which millennials thrive. Perceived fulfilment of their PC in this area of career development encouraged the YMPs to adopt a higher level of engagement with what they saw as their obligations to the organisation in terms of their current and future roles, thus positively influencing their performance. It enhanced their affective commitment, implying that these young workers felt a strong emotional attachment to the organisation and their work. They identified with the organisation's goal and values, which in turn met their need for meaningful work. Higher affective commitment is positively associated with actual performance and lower turnover (Zhao et al., 2007).

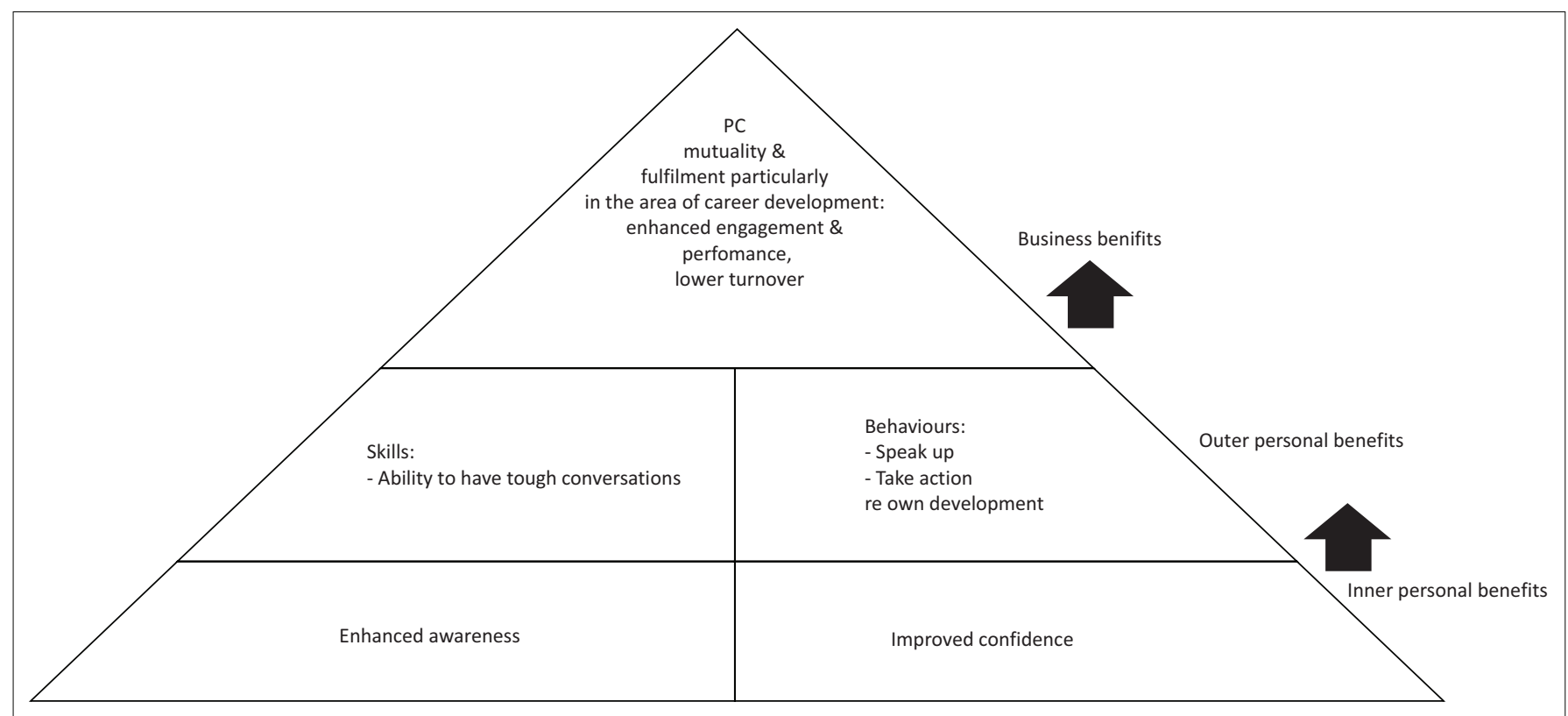

Source: Adapted from Leedham, M. (2005). The coaching scorecard: A holistic approach to evaluating the benefits of business coaching. International Journal of Evidence Based Coaching and Mentoring, 3(2), 30-44

PC, psychological contract.

FIGURE 1: Coaching and psychological contract alignment pyramid. 
Psychological contract mutuality and fulfilment flowing from coaching outcomes may result in YMPs who perform at a higher level of engagement and see their future growth and career aspirations being realised in the organisation, specifically addressing the challenge faced by organisations to engage and retain YMPs. Mutually beneficial outcomes valued by both the coachee and the organisation are realised.

\section{Acknowledgements Competing interests}

The authors declare that they have no financial or personal relationships that may have inappropriately influenced them in writing this article.

\section{Authors' contributions}

C.S. conducted the research as part of her dissertation for the fulfilment of the degree of Master of Philosophy in Management Coaching and wrote the article. S.v.C.-P. supervised the research and reviewed and edited the article.

\section{Funding information}

This research received no specific grant from any funding agency in the public, commercial or not-for-profit sectors.

\section{Data availability statement}

Data sharing is not applicable to this article as no new data were created or analysed in this study.

\section{Disclaimer}

The views and opinions expressed in this article are those of the authors and do not necessarily reflect the official policy or position of any affiliated agency of the authors.

\section{References}

Alsop, R. (2008). The trophy kids group up: How the Millennial generation is shaping up the workplace. San Francisco, CA: Jossey-Bass.

Babbie, E., \& Mouton, J. (2015). The practice of social research. Cape Town: Oxford University Press Southern Africa (Pty) Ltd.

Braun, V., \& Clarke, V. (2006). Using thematic analysis in psychology. Qualitative Research in Psychology, 3(2), 77-101. https://doi.org/10.1191/1478088706qp063oa

Burrows, T. (2013). Managing the millennial gap. Retrieved from https://mg.co.za/ article/2013-08-30-00-managing-the-millennial-gap.

Cennamo, L., \& Gardner, D. (2011). Generational differences in work values, outcomes and person-organisation values fit. IEEE Engineering Management Review, 39(2) 24-36. https://doi.org/10.1109/EMR.2011.5876170

Coetzee, M., Ferreira, N., \& Shunmugum, C. (2017). Psychological career resources, career adaptability and work engagement of generational cohorts in the media industry. SA Journal of Human Resource Management/SA Tydskrif vir Menslikehulpbronbestuur, 15(0), a868. https://doi.org/10.4102/sajhrm.v15i0.868

Conway, N., Guest, D., Sturges, J., \& Liefooghe, A. (2005). Managing the career deal: The psychological contract as a framework for understanding career management organizational commitment and work behavior. Journal of Organisational Behavior, 26, 821-838. https://doi.org/10.1002/job.341

Coyle-Shapiro, J., \& Kessler, I. (2000). Consequences of the psychological contract for the employment relationship: A large-scale survey. Journal of Management Studies, 37(7), 903-930. https://doi.org/10.1111/1467-6486.00210

Coyle-Shapiro, J.A.M., \& Kessler, I. (2002). Exploring reciprocity through the lens of the psychological contract: Employee and employer perspectives. European Journal of Work and Organizational Psychology, 11(1), 69-86. https://doi. org/10.1080/13594320143000852
Creswell, J.W. (2007). Qualitative inquiry and research design: Choosing among the five traditions (2nd edn.). Thousand Oaks, CA: Sage.

Crowe, M., Inder, M., \& Porter, R. (2015). Conducting qualitative research in mental health: Thematic and content analyses. Australian \& New Zealand Journal of Psychiatry, 49(7), 616-623. https://doi.org/10.1177/0004867415582053

Dabos, G.E., \& Rousseau, D.M. (2004). Mutuality and reciprocity in the psychological contracts of employees and employers. Journal of Applied Psychology, 89(1) 52-72. https://doi.org/10.1037/0021-9010.89.1.52

De Hauw, S., \& De Vos, A. (2010). Millennials' career perspective and psychological contract expectations: Does the recession lead to lowered expectations? Journal of Business and Psychology, 25(2), 293-302. https://doi.org/10.1007/s10869010-9162-9

Deloitte. (2016). The Deloitte 2016 millennial survey: Executive summary. Retrieved from https://www2.deloitte.com/content/dam/Deloitte/global/Documents/ About-Deloitte/gx-millenial-survey-2016-exec-summary.pdf.

Denzin, N.K., \& Lincoln, Y.S. (2005). The Sage handbook of qualitative research (3rd edn.). Thousand Oaks, CA: Sage.

Douglas, C., \& McCauley, C.D. (1999). Formal developmental relationships: A survey of organizational practices. Human Resource Development Quarterly, 10(1) of organizat $203-220$.

Dries, N., Pepermans, R., \& De Kerpel, E. (2008). Exploring four generations' beliefs about career: Is 'satisfied' the new 'successful'? Journal of Managerial Psychology, 23(8), 907-928. https://doi.org/10.1108/02683940810904394

Festing, M., \& Schafer, L. (2014). Generational challenges to talent management: A framework for talent retention based on the psychological contract perspective. Journal of World Business, 49(2), 262-270. https://doi.org/10.1016/j.jwb.2013. 11.010

Franklin, H. (2015). Coaching millennial leaders: Life stage versus the times we live in International Journal of Evidence Based Coaching and Mentoring, Special Issue, (9), 63-76.

Freese, C., \& Schalk, R. (2005). How to measure the psychological contract? A critical criteria-based review of measures. South African Journal of Psychology, 38(2), 269-286. https://doi.org/10.1177/008124630803800202

Gibson, L. (2010). Using email interviews. Realities toolkit\# 09. ESRC National Centre for Research Methods. Retrieved from www.socialsciences.manchester.ac.uk/ morgancentre/realities/toolkits/email-interviews/index.html

Gosse, D. (2017). Transcript of Simon Sinek's millennials in the workplace interview. Retrieved from http://ochen.com/transcript-of-simon-sineks-millennials-in-theworkplace-interview.

Grant, M.A., Curtayne, L., \& Burton, G. (2009). Executive coaching enhances goal attainment, resilience and workplace well-being: A randomised controlled study. The Journal of Positive Psychology, 4(5), 396-407. https://doi. org/10.1080/17439760902992456

Grenny, J., Patterson, K., Maxfield, D., McMillan, R., \& Switzler, A. (2013). Influencer: The new science of leading change (2nd edn.). New York: McGraw-Hill Education.

Henderson, G. 2016. The link between confidence and self-awareness. Retrieved from https://www.linkedin.com/pulse/link-between-confidence-self-awareness-granthenderson.

Herriot, P., Manning, W.E.G., \& Kidd, J.M. (1997). The content of the psychological contract. British Journal of Management, 8(2), 151-162. https://doi. org/10.1111/1467-8551.0047

Hess, N., \& Jepsen, D.M. (2009). Career stage and generational differences in psychological contracts. Career Development International, 14(3), 261-283. https://doi.org/10.1108/13620430910966433

International Coaching Federation (ICF). (2017). Retrieved from https://www. coachfederation.org/need/landing.cfm?ItemNumber=978\&navltemNumber= 567.

Jones, R.J., Woods, S.A., \& Guillaume, Y.R.F. (2016). The effectiveness of workplace coaching: A meta-analysis of learning and performance outcomes from coaching. Journal of Occupational and Organizational Psychology, 89(2), 249-277. https:// doi.org/10.1111/joop.12119

Kahn, M.S. (2014). Coaching on the axis: Working with complexity in business and executive coaching. London: Karnac Books.

Kombarakaran, F.A., Yang, J.A., Baker, M.N., \& Fernandes, P.B. (2008). Executive coaching: It works! Consulting Psychology Journal Practice and Research, 60(1), 78-90. https://doi.org/10.1037/1065-9293.60.1.78

Kultalahti, S., \& Viitala, R. 2015. Generation Y - Challenging clients for HRM. Journal of Managerial Psychology, 30(1), 101-114. https://doi.org/10.1108/JMP-08-20140230

Leedham, M. (2005). The coaching scorecard: A holistic approach to evaluating the benefits of business coaching. International Journal of Evidence Based Coaching and Mentoring, 3(2), 30-44

Le Sueur, H.M., \& Tapela, V. (2018). Conditions for coaching to contribute to the adjustment of black African professionals. SA Journal of Human Resource Management/SA Tydskrif vir Menslikehulpbronbestuur, 16(0), a946. https://doi. org/10.4102/sajhrm.v16i0.946

Low, C.H., Bordia, P., \& Bordia, S. (2016). What do employees want and why? An exploration of employees' preferred psychological contract elements across career stages. Human Relations, 69(7), 1457-1481. https://doi.org/10. $1177 / 0018726715616468$

Lub, X.D., Bal, P.M., Blomme, R.J., \& Schalk, R. (2016). One job, one deal...or not: International Journal of Human Resource Management, 27(6), 653-680. https:// doi.org/10.1080/09585192.2015.1035304 
Lub, X.D., Blomme, R.J., \& Bal, P.M. (2011). Psychological contract and organisational citizenship behaviour: A new deal for new generations? Advances in Hospitality citizenship behaviour: A new deal for new generations? Advances in Hospitality
and Leisure, 7, 109-130. https://doi.org/10.1108/S1745-3542(2011)0000007010

Lyons, S.T., \& Kuron, L. (2014). Generational differences in the workplace: A review of evidence and directions for future research. Journal of Organisational Behaviour, 35, 139-157. https://doi.org/10.1002/job.1913

Myers, K.K., \& Sadaghiani, K. (2010). Millennials in the workplace: A communication perspective on millennials' organizational relationships and performance. Journal of

Ng, E.S.W., Schweitzer, L., \& Lyons, S.T. (2010). New generation, great expectations: A field study of the millennial generation. Journal of Business and Psychology, 25(2) 281-292. https://doi.org/10.1007/s10869-010-9159-4

Persson, S., \& Wasieleski, D. (2015). The seasons of the psychological contract: Overcoming the silent transformations of the employer-employee relationship. Human Resource Management Review, 25(4), 368-383. https://doi.org/10.1016/j hrmr.2015.02.003

PWC. (2011). GenY reshaping the workplace. Retrieved from https://www.pwc. $\mathrm{com} / \mathrm{gx} / \mathrm{en} / \mathrm{managing}$-tomorrows-people/future-of-work/assets/reshaping-theworkplace.pdf.

Rabionet, S.E. (2011). How I learned to design and conduct semi-structured interviews: An ongoing and continuous journey. The Qualitative Report, 16(2), 563-566.

Rousseau, D.M. (1990). New hire perceptions of their own and their employer's obligations: A study of psychological contracts. Journal of Organizational Behavior, 11(5), 389-400. https://doi.org/10.1002/job.4030110506

Rousseau, D.M. (1995). Psychological contracts in organizations: Understanding written and unwritten agreements. Thousand Oaks, CA: Sage.

Rousseau, D.M. (2001). Schema, promise and mutuality: The building blocks of the psychological contract. Journal of Occupational and Organizational Psychology, 74(4), 511-541. https://doi.org/10.1348/096317901167505

Rousseau, D.M. (2004). Psychological contracts. Academy of Management Executive, 18(1), 120-127.

Sherpa Coaching. (2017). Sherpa executive coaching survey public report 2017. Retrieved from http://www.sherpacoaching.com/annual-executive-coachingsurvey/.
Silvia, P.J., \& O'Brien, M.E. (2004). Self-awareness and constructive functioning: Revisiting 'the human dilemma'. Journal of Social and Clinical Psychology, 23(4), 475-489. https://doi.org/10.1521/jscp.23.4.475.40307

Simpson, J. (2010). In what ways does coaching contribute to effective leadership development? International Journal of Evidence Based Coaching and Mentoring, 4(10), 114-133.

Twenge, J.M. (2010). A review of the empirical evidence on generational differences in work attitudes. Journal of Business and Psychology, 25(2), 201-210. https://doi. org/10.1007/s10869-010-9165-6

Twenge, J.M., \& Campbell, S.M. (2012). Who are the Millennials? Empirical evidence for generational differences in work values, attitudes and personality. In E. Ng, S.T. Lyons, \& L. Schweitzer (Eds.), Managing the new workforce: International perspectives on the Millennial generation (pp. 1-19). Cheltenham: Edward Elgar perspectives on the
Publishing Limited.

Twenge, J.M., Campbell, S.M., Hoffman, B.R., \& Lance, C.E. (2010). Generational differences in work values: Leisure and extrinsic values increasing, social and intrinsic values decreasing. Journal of Management, 36, 1117-1142. https://doi. org/10.1177/0149206309352246

Wasserman, H. 2017. Managing millennials. Retrieved from http://www.fin24.com/ Finweek/Featured/managing-millennials-20170306.

Wong, M., Gardiner, E., Lang, W., \& Coulon, L. (2008). Generational differences in personality and motivation: Do they exist and what are the implications for the workplace? Journal of Managerial Psychology, 23(8), 878-890. https://doi. org/10.1108/02683940810904376

Wray-Lake, L., Syvertsen, A.K., Briddell, L., Osgood, D.W., \& Flanagan, C.A (2011). Exploring the changing meaning of work for American high school seniors from 1976 to 2005 . Youth \& Society, 43, 1110-1135. https://doi. seniors from 1976 to 2005. Youth
org/10.1177/0044118X10381367

Ye, J., Cardon, M.S. \& Rivera, E. (2012). A mutuality perspective of psychological contracts regarding career development and job security. Journal of Business Research, 65(3), 294-301. https://doi.org/10.1016/j.jbusres.2011.03.006

Zhao, H. Wayne, S., Glibkowksi, B., \& Bravo, J. (2007). The impact of psychological contract breach on related work-outcomes: Meta analysis. Personnel Psychology, 60, 647-680. https://doi.org/10.1111/j.1744-6570.2007.00087.x 